\title{
Enhancing energy literacy in children using zn/cu/potato
}

\section{batteries [version 1; peer review: 2 approved, 1 approved with}

\section{reservations]}

\author{
Mark Polikovsky, Avigdor Sharon, Alexander Golberg
}

Porter School of Environmental Studies, Tel Aviv University, Tel Aviv, Israel

V1 First published: 08 Jan 2018, 7:24

https://doi.org/10.12688/f1000research.13228.1

Latest published: 08 Jan 2018, 7:24

https://doi.org/10.12688/f1000research.13228.1

\section{Abstract}

Background. The major challenges that prevent the wide-scale adoption of emerging personal clean energy production are unawareness and low self-confidence. We tested a hypothesis that a combination of a new technology and educational methods could lead to the increase in awareness of children to clean energy possibilities and to an increase in self-confidence in applying them.

Methods. Here we report on a toolkit that combines low carbon, clean energy source, $\mathrm{Zn} / \mathrm{Cu} /$ potato batteries, sufficient to power lightemitting diodes, with a non-formal education by experience program, based on case studies and hands-on experience with battery assembly for 6-11 years old children, led by trained 12-14 old youth leaders.

Results. The results show that the education experience increased the awareness of the children to produce electricity at home from unconventional, yet available raw materials and their self-confidence in being able to do this $(p=0.008)$.

Conclusions. The developed toolkit supports environmental and energy literacy education through non-formal training, increasing awareness and self-confidence in children to actually apply this in their living environment to produce clean energy.

\section{Keywords}

energy education, batteries, lighting, household air pollution prevention, bioelectricity

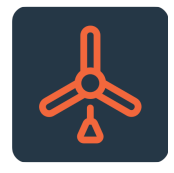

This article is included in the Energy gateway.

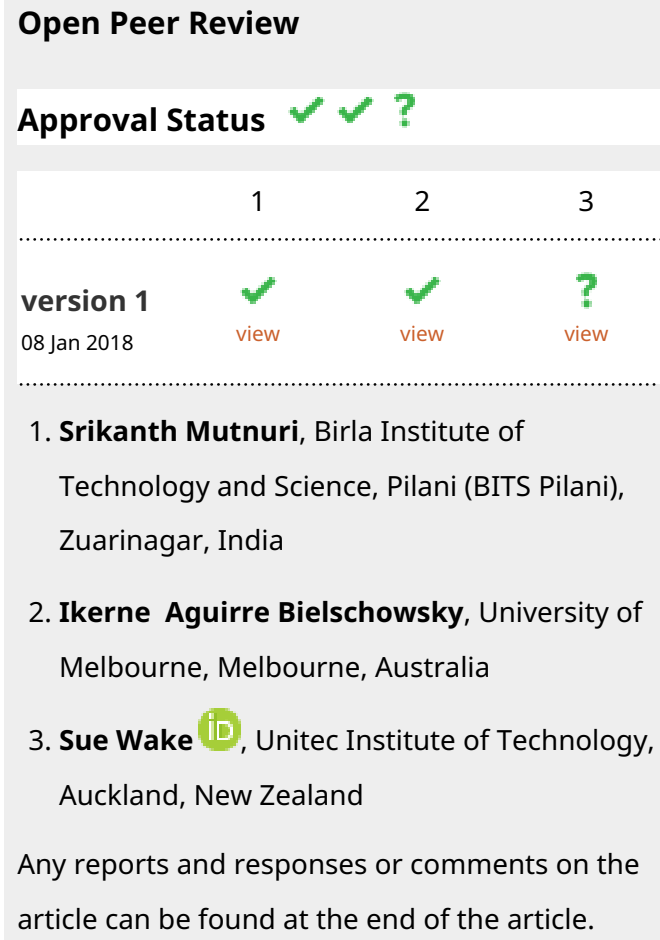

1. Srikanth Mutnuri, Birla Institute of Technology and Science, Pilani (BITS Pilani), Zuarinagar, India

2. Ikerne Aguirre Bielschowsky, University of Melbourne, Melbourne, Australia

3. Sue Wake (iD), Unitec Institute of Technology, Auckland, New Zealand

Any reports and responses or comments on the article can be found at the end of the article. 
Corresponding author: Alexander Golberg (agolberg@gmail.com)

Author roles: Polikovsky M: Conceptualization, Data Curation, Formal Analysis, Investigation, Methodology, Validation, Writing Original Draft Preparation, Writing - Review \& Editing; Sharon A: Conceptualization, Formal Analysis, Investigation, Methodology, Validation, Visualization, Writing - Original Draft Preparation, Writing - Review \& Editing; Golberg A: Conceptualization, Formal Analysis, Investigation, Methodology, Project Administration, Resources, Supervision, Validation, Writing - Original Draft Preparation, Writing Review \& Editing

Competing interests: No competing interests were disclosed.

Grant information: The author(s) declared that no grants were involved in supporting this work.

Copyright: @ 2018 Polikovsky $\mathrm{M}$ et al. This is an open access article distributed under the terms of the Creative Commons Attribution License, which permits unrestricted use, distribution, and reproduction in any medium, provided the original work is properly cited. Data associated with the article are available under the terms of the Creative Commons Zero "No rights reserved" data waiver (CCO 1.0 Public domain dedication).

How to cite this article: Polikovsky $M$, Sharon $A$ and Golberg $A$. Enhancing energy literacy in children using zn/cu/potato batteries [version 1; peer review: 2 approved, 1 approved with reservations] F1000Research 2018, 7:24 https://doi.org/10.12688/f1000research.13228.1

First published: 08 Jan 2018, 7:24 https://doi.org/10.12688/f1000research.13228.1 


\section{Introduction}

Children are the decision-makers of the future and will bear the brunt of the energy-environment- climate crisis $^{1-3}$. The USA Department of Energy Literacy guide stays:

Without a basic understanding of energy, energy sources, generation, use and conservation strategies, individuals and communities cannot make informed decisions on topics ranging from smart energy use at home and consumer choices to national and international energy policy.

A study of USA youth ${ }^{5}$ revealed that "students did not have a sound knowledge and understanding of basic scientific energy resources facts, issues related to energy sources and resources, general trends in the U.S. energy resource supply and use. The students also did not understand the impact of energy resource development and use on society and the environment" 5 . Similar results were observed in recent studies with New Zealand ${ }^{6}$ and Taiwanese ${ }^{7}$ youth, who mostly looked at energy in monetary terms and knew little of its environmental impacts. A UK study showed "that children derived more motivation to save energy from responsibility conferred by school activities than other (e.g. environmental) concerns, and some connected energy saving with dangers of using electricity (e.g. fire)"

Most children learn about energy issues from parents ${ }^{6,8}$. Therefore, the energy literacy of young persons in low income countries is lower than in OECD countries because of the general population's unawareness of renewable energy potential and of energy impacts on health and the environment ${ }^{9}$. Developing education tools to increase awareness to the effect of energy production on health and environmental problems is a major challenge, required to make a change in this sector.
Our long-term goal is to increase energy literacy among children by creating awareness to the hazards of toxic and polluting materials, the benefits of clean energy, and the possibilities of creating clean energy at home. Subsequently, to encourage learning and actual implementation, resulting in a behavior shift towards using clean energy on an on-going basis.

To achieve this goal it is important to provide not only the required knowledge, but also to develop interest, care and a perception of personal ability. These are all attributes of environmental literacy. Environmental literacy is the ability to understand the environmental systems that we live in, their importance and impact on us, as well as our own well-being requirements and to take the measures required to interact with the environment in a responsible fashion and to benefit from it while sustaining it for the long term ${ }^{10}$. It requires both cognitive and affective elements, encompassing knowledge, affects, skills and behavior, which are all important to develop responsible environmental behavior ${ }^{10-12}$. As people develop their environmental literacy, they progress gradually from a basic, nominal level of their knowledge, emotions, skills and behavior to functional and operational levels (Figure 1a). Though each individual has a unique journey through the continuum of environmental literacy development, it is usual to go from initial awareness to developing personal concern and then better understanding and a perception of personal ability before deciding to take action ${ }^{10}$ (Figure 1b).

Gaining knowledge does not necessarily lead to developing proenvironmental attitude, care and values. Developing attitudes does not necessarily lead to taking action and to adopting environmentally responsible behavior ${ }^{13,14}$. Some triggers or specific ingredients of the learning experience and of life experience as a whole seem to be required to develop responsible environmental and energy-wise

a

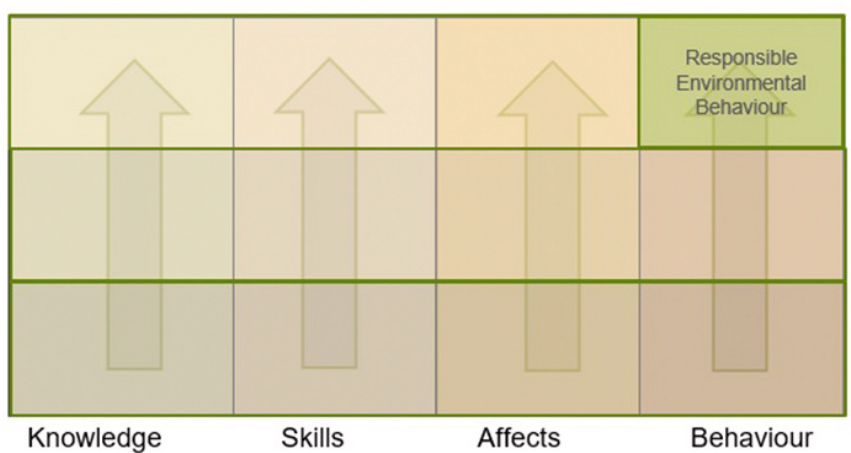

Operational

Functional

Nominal

b

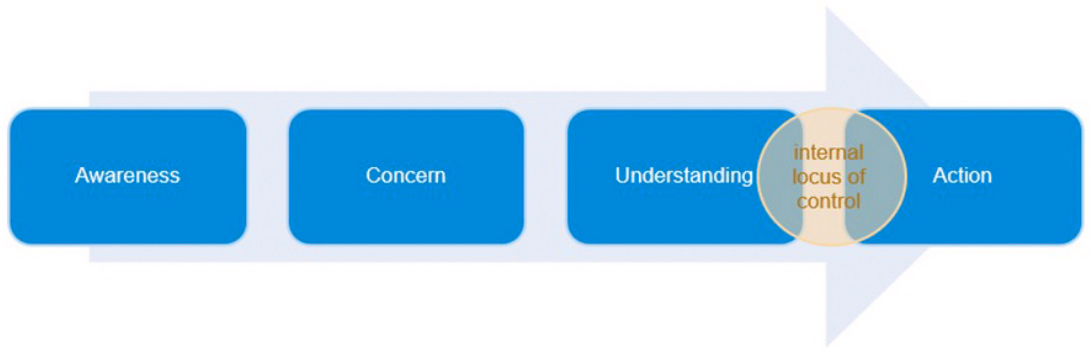

Figure 1. Developing Environmental and Energy-responsible literacy. (a) From rudimentary knowledge and budding awareness to responsible environmental behavior: the environmental literacy continuum. (b) The stages of developing environmental and energy-responsible literacy in education. 
behavior. Such ingredients are personal experience and emotions, curiosity, sense of wonder and excitement ${ }^{15-20}$

Previous works suggested various scenarios to develop energy literacy through a standard curriculum in classes ${ }^{21}$. An alternative approach is an outdoor, non-formal education. Indeed, outdoor education, in a non-formal setting, was found to result in better behavioral outcomes in comparison to traditional classroom learning ${ }^{22}$. Several important attributes such as concentration, agility, emotional expressions, and communication were found to be higher in the outdoor education setting. It was reported that "Outdoor education influenced behavioral changes in a positive direction" 22 . Non-formal education at various settings provides new opportunities for learning and benefits for both the effective and cognitive axis of human behavior, inciting interest, positive attitudes and fond memories that persist over time ${ }^{23}$. The non-formal education, in an outdoors or community settings, is beneficial and synergistic with both school learning and family engagement ${ }^{24}$. Therefore, it is of an important significance in developing environmental and energy literacy and in nurturing responsible energy and environmental behavior in communities and families. Consequently, novel tools are needed to nurture this behavior.

More than two centuries ago, Luigi Galvani's pioneering research of the electrical properties of biological tissues discovered "bioelectricity". Inspired by those results, Alessandro Volta invented a device capable of producing electricity by the mere contact of conducting substances of different species" ${ }^{25}$. This device, the "Voltaic battery', marked the birth of a new era in the development of modern physics and important changes in our lifestyle by using batteries. The key advantage of batteries is their ability to store and deliver portable, off-the-grid electricity.

In the application for lighting in low-income off-grid communities, batteries already allow for the transition from fuel to electric-based lighting and could reduce health risks ${ }^{26}$. In addition, by supporting the elimination of fuel-based light sources, they would also contribute to the reduction in greenhouse gas emissions $^{27}$, weaning governments of the burden of fuel subsidies that often exceed expenditures on healthcare and, importantly, provide new jobs ${ }^{28,29}$. However, improperly disposed commercial batteries contaminate the environment with heavy metals such as mercury, lead, cadmium, and nickel. In addition, battery energy is the key cost component in all low-cost devices recently developed for low-income communities ${ }^{30-33}$.

To address the problems of availability, cost and environmental impact, we introduced vegetative batteries, based on $\mathrm{Zn} / \mathrm{Cu}$ and potatoes with disintegrated cell walls. Preliminary cost analysis showed that a $\mathrm{Zn} / \mathrm{Cu}$-Potato battery is able to produce portable energy at $\sim 7 \$ / \mathrm{kWh}$, which is significantly lower than current available 1.5 Volt AA alkaline cell $(\sim 450 \$ / \mathrm{kWh}$ (retail)), flow $(\sim 600 \$ / \mathrm{kwh})^{34}$, advanced lead-acid $(900 \$ / \mathrm{kWh})^{34}$, lithium ion $(500 \$ / \mathrm{kWh})^{34}$ or $\mathrm{D}$ cells $(\sim 49-84 \$ / \mathrm{kWh})^{35}$. The basic battery cell design and resulting LED light (Figure 2) allows for reading a book in a completely dark room (Figure 2d). In comparison to kerosene lamps with lighting efficiency of
0.08-0.11 lm/watt, light-emitting diode (LED)- $\mathrm{Zn} / \mathrm{Cu}$-boiled potato battery provides $8.3-53.1 \mathrm{~lm} /$ watt. At the same time, cost of light is $0.13-0.85 \$ / 1000 \mathrm{~lm} \cdot \mathrm{h}$, while for kerosene lamps it is $3.69-5.81 \$ / 10001 \mathrm{~m} \cdot \mathrm{h}^{35}$. This study was followed by a paper from Sri Lanka, which reported 500 hours operation LED with $\mathrm{Zn} /$ boiled plantain pith battery ${ }^{36}$. Yet, the rate of adaptation of new technologies in population is low. Low awareness and low self-confidence contribute to these low rates of technology $\operatorname{adaptation}^{37}$.

The goal of this work is to test the working hypothesis that $\mathrm{Zn} / \mathrm{Cu}$-boiled potato battery technology, taught using participatory outdoors educational methods, could lead to the increased awareness and self-confidence of young children in actually producing clean energy at home.

\section{Methods}

Study subjects

96 children aged 6-11 years and 11 youth guides $12-14$ years old from Israel participated in the study in the "Teva HaSviva" summer camp in July-August 2015. Written informed consent was obtained from parents before the camp for their children's participation in the study as part of their camp activities, according to the Israel law, by "Teva HaSviva". The parents and the children were informed that the camp runs experimental educational programs in various branches of environmental education.

\section{$\mathrm{Zn} / \mathrm{Cu} /$ potato battery assembly}

We developed an easy to use toolkit for light generation from LEDs. The important aspect of the potato battery toolkit (Figure 2a) is that it can be readily assembled at any home or any outdoor activity in the majority of the countries in the World. The basic elements of the battery are $\mathrm{Zn}$ and $\mathrm{Cu}$ electrodes, wires, LED, knife, boiled potatoes (Figure 2a). The steps for battery preparation, assembly, and testing appear in Figure 2b. Although in these studies we used conventional boiling, used by families to cook, alternative cleaner energy strategies, such as solar cooker can be used ${ }^{38}$.

In this work, we developed a "Make yourself a battery" toolkit to teach youth energy and environment issues with the potential to provide light and prevent household poisoning. We demonstrated the use of the kit as an educational tool in a pilot study with 96 children 6-11 years old. This kit can be used as an energy and environment educational technology for the outdoor educational activities. In addition, it can displace the kerosene lamp for reading in medium and low-income countries. The kit provides a low-cost technology that can serve the dual purposes of improving lighting efficiency and increasing environmental and energy literacy by removing unawareness and low self-confidence, which are major barriers for the introduction of new energy systems to low-income countries.

During the activity, the children used boiled potatoes, $\mathrm{Zn}$ and $\mathrm{Cu}$ electrodes $(5 \mathrm{X} 10 \mathrm{~cm})$, wires, resistors, voltmeter and LEDs, as described Figure 2a. The assembly protocol for each cell and the complete battery, which consists of several cells connected in series, is shown in Figure $2 b$ and c. Figure 2 shows a step-by-step procedure for battery assembly and use to generate LED light sufficient for reading (Figure 2d) 
a
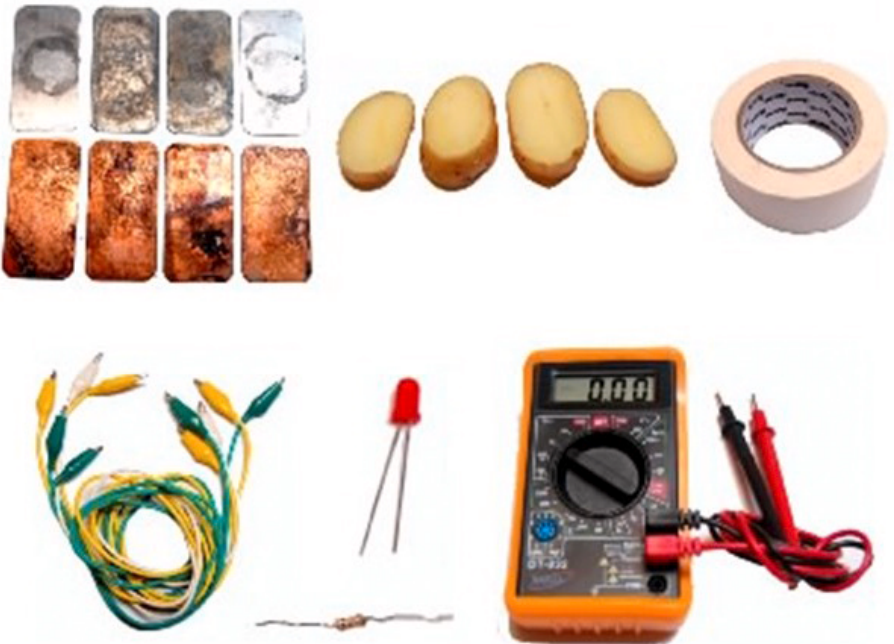

C

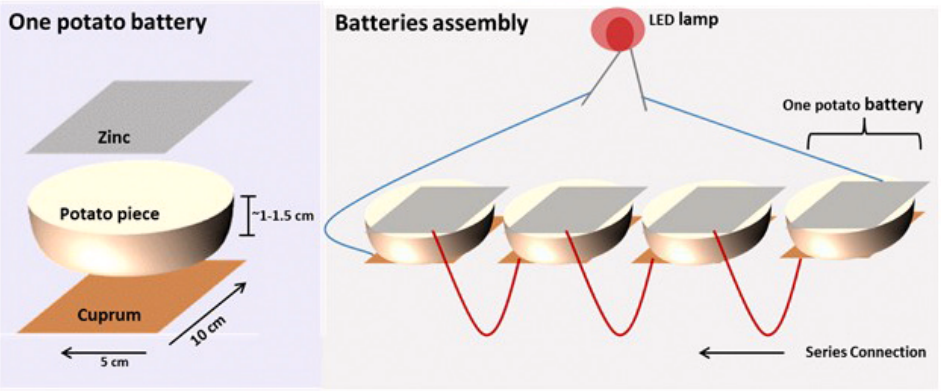

b

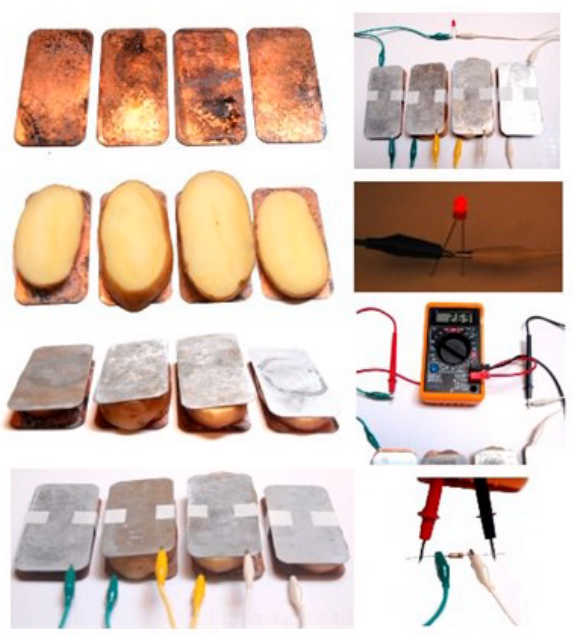

d

Figure 2. "Make yourself a battery" toolkit. (a) Basic components required to assemble a battery at home. Zinc and Copper plates $(\sim 5 \times 10 \mathrm{~cm})$, wires, boiled potato, sealing tape, light emitting diode (LED). Test resistor and voltmeter are used for performance measurements. (b) Process for a single cell and complete battery assembly. Assembly description of four potato batteries to turn on one LED lamp (i) put 4 plates on a rigid substrate; (ii) add 4 boiled slices of potato, once cooled, on the metal plates, recommended to cover the metal plates with the potatoes, as much as possible; (iii) cover the potatoes with the Zn plates; (iv) seal the cells with a tape and connect the batteries with the cables - each metal should be connected to the closest battery to the second metal except to metal plates on the edges; (v) connect the not connected plates, to the LED lamp, the electric circle is closed; (vi) in a case everything connected right, the LED lamp will be turned on; (vii) to measure open circuit voltage, a voltmeter should be connected instead the lamp; (viii) to measure the current in the system, connect the 100ohm resistor instead of the LED and measure the voltage on it. (c) Schematic representation of a complete lighting device, powered by $\mathrm{Zn} / \mathrm{Cu} /$ boiled potato battery. (d) Lighting device performance example for book page illumination in a completely dark room.

\section{$\mathrm{Zn} / \mathrm{Cu} /$ potato battery performance evaluation}

The thickness of each galvanic cell was measured by ruler ( $1 \mathrm{~mm}$ resolution). The working surface area was measured in digital images of each galvanic cell using ImageJ (ver 1.48r 18) program (NIH, ML). Open circuit voltage and the voltage on the $100 \mathrm{ohm}$ resistor were measured using a digital voltmeter (0.01 V resolution). Current flowing on the resistor was calculated by Ohm's law as I=V/R. Power was calculated as $\mathrm{P}=\mathrm{I} \cdot \mathrm{V}$. The current and power density were calculated by equations $i=\mathrm{I} / \mathrm{A}$ $\left(i=\right.$ current density, $\mathrm{A}=$ area in $\mathrm{cm}^{2}$ ) and $\mathrm{p}=\mathrm{P} / \mathrm{A}$, respectively ${ }^{39}$.

Pilot study design: Educational program to provide early age education for generating clean electricity for light

To increase energy literacy and the use of the "Make yourself a battery" toolkit, we designed the following pilot study. First, we further developed the technology of batteries based on $\mathrm{Zn}$ and boiled potatoes ${ }^{35}$, which can be easily used in low-income communities. Second, we assessed the pre-learning energy literacy of a group of children. Third, we performed a hands-on activity with the children who assembled and characterized the $\mathrm{Zn} / \mathrm{boiled}$ potato batteries. Finally, we assessed the post-learning energy literacy of this group of children.

To enhance the environmental and energy literacy in youth we developed an outdoor activity that can teach children about energy conversion and light generation. The study was conducted at the "Teva Hasviva" summer camp at Tel-Aviv University, Israel in 2015. The camp takes place during every school vacation period that is at least 1 week long, throughout the year. The core themes of "Teva Hasviva" camps are sustainable living, care for nature and ecological literacy. The core mission of the camps is to foster environmental literacy, synergy with nature in and around the city, nature conservation and a healthy lifestyle. This is done in an enjoyable setting, learning by experience in a combined outdoors and 
university campus environment, having fun, leading activities with a practical contribution to the natural environment and to the community, research and discovery.

The study design is shown in Figure 3a. The summer activity is also a part of a 3-year qualification program for youth guides. For this study, we first trained young youth guides (12-14 years old), participating in a course during the same summer camp $(\mathrm{N}=11)$. The trained youth guides performed all the activities with children (6-11 years old, $\mathrm{N}=96$ ), who participated in a 2 -week summer camp. Additional activities for participating children included visiting natural open spaces near the city and conducting animals and plants surveys, building nesting boxes for birds, making creative artifacts from packaging materials to avoid dumping, learning to make healthy, natural food, plant ecological gardens, in a learning-by-doing approach (Supplementary File 1 and Figure 3b). Each part of the activities took 30-40 min.

The targets of the education activity were defined as follows:

1. Theoretical introduction to energy in nature and society.

2. Youth guides will learn how to teach and how to perform an experiment and then perform the experiment with the children.

3. Children will learn about concepts of energy generation and its application to affluent and low-income countries problems.

4. Children will learn of the actual production of electricity from $\mathrm{Zn} / \mathrm{Cu}$ /potato batteries as an educational activity and as a tool for them to make their own battery to use.
5. Development of energy education tool and protocol for rapid batteries assemblies for low- income remote communities.

Youth guides, who participate in the three-year environmental leadership program of the camp, were instructed before their activity on the method to assemble the battery and measure the outputs of produced electricity. They practiced the theory of what they learned during the theoretical presentation. Moreover, they learned how to use the voltmeter to measure voltage and current and measure effective electrolyte surface area by digital photography. Each of the youth guides led a group of 5-8 children during the practical battery assembly activity. The assembly was done in a form of competition between groups. Youth guides taught the children about electricity production from batteries for lighting and showed them how to use the voltmeter. The winner was the team with maximum generated voltage. Youth guides were also responsible to collect measurements from the assembled batteries such as electrolyte area, number of connectedin-series cells, total voltage and current (Table S1 and Table S2).

In addition, to demonstrate to children that it is possible to provide human needs without damaging the environment, the complete life cycle of potatoes used in the process was shown (Figure S1). After the activity, all used potatoes were composted. No leftovers were thrown away. We explained that the composted potatoes could be used for fertilization. We explained that the metal plates, cables, and LED lamps could be reused for additional activates. This way we introduced the entire cradle-to-cradle lifecycle of all materials used. We described a process where we minimize any use of materials that could not be naturally recycled. In places where the teaching a

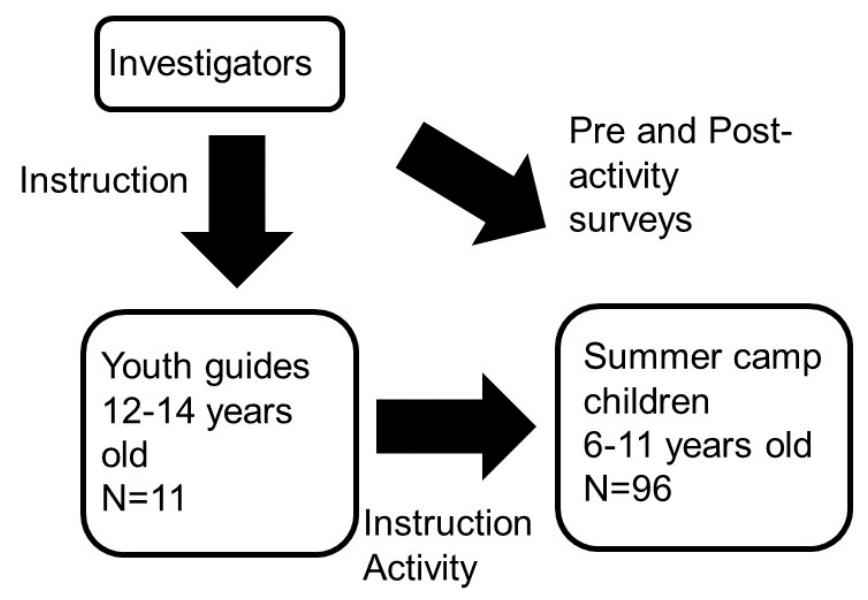

b
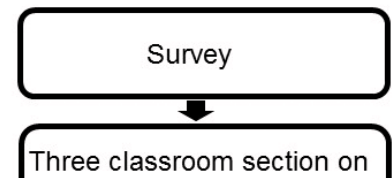

bioenergy systems
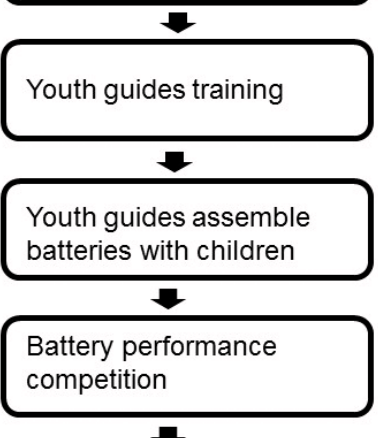

Survey

Figure 3. Educational activity description. (a) The schematic description of the educational activity involving youth leader and children in the summer camp. (b) Teaching materials, lectures, and activity structure as performed during the camp. 
period is longer than a few weeks (as was in our case), and the places include area for potato growth and compost it can be useful to show the children the potato lifecycle before and after the activity, including cultivation of new potatoes using the compost from the previous ones. This activity can also be integrated with a field implementation of solar cookers ${ }^{38}$.

\section{Learning process evaluation}

A short pre-learning questionnaire and a matching short postlearning questionnaire were used. In both questionnaires, Likert-type questions (a 1-5 scale) for quantitative assessment of levels of knowledge, skills and attitudes and open text questions for qualitative analysis were used (Table 1, see Supplementary File 2 for detailed questionnaire structure). The questions addressed the major areas of environmental and energy literacy continuum with an emphasis on affects as a key to literacy development. Pre-learning questions were designed to find out the extent of awareness and the level of knowledge before the learning session took place. Post-learning questions were designed to find out what participants have learned and understood, what they remember and what was their attitude towards the information and insights from the learning session. All 96 children participating in the summer camp received the pre-learning questionnaire 4 days before the learning session. They received the postlearning questionnaire 4 days after the learning session. Both questionnaires were provided in a very casual, relaxed atmosphere during a time break at the orchard area where the children had lunch and rested. The questionnaire was kept short to make it easy for the children to reply to it despite distractions in the field. The results were then analyzed and compared.

\section{Statistical analysis}

In addition to descriptive statistics for the Likert-scale questions, Pearson correlation was computed to assess the relationship between answers to questions in the Likert-type questionnaire. Correlations are reported in APA style with the syntax $r=$ Pearson's correlation value, $\mathrm{p}=$ significance value. Student's t-test (2-tailed, $\mathrm{DF}=$ is shown for each t-test result) was used to examine differences in variables before and after the learning session. All analysis was done with IBM SPSS Statistics ver 23 (IBM, NY).

Some questions before and after the learning session were not exactly the same, therefore, no $\mathrm{T}$ value was calculated (before: "I think it will be interesting for me to learn about energy in nature", after: "It was interesting for me to learn about energy in nature").

\section{Results and discussion}

The electricity production from boiled potato batteries with $\mathrm{Zn} / \mathrm{Cu}$ electrodes

The generated voltage, current, power, current density and power density from the assembled batteries are shown in Figure 4. The longest assembled by children battery consisted of 23 individual cells (Figure 4a). The largest generated open circuit voltage was 16.55 Volt (Figure 4b). The largest current was $2.8 \mathrm{~mA}$ (Figure 4c),

Table 1. Pre- and post-learning activity questions, addressing the major elements of environmental literacy.

\begin{tabular}{|c|c|c|}
\hline & Pre & Post \\
\hline \multirow[t]{7}{*}{ Knowledge } & Electricity is always available. It never runs out & Electricity is always available. It never runs out \\
\hline & It is possible to create electricity on our own & It is possible to create electricity on our own \\
\hline & Which ways do we get or create electricity & Which ways do we get or create electricity \\
\hline & How can we create electricity on our own & How can we create electricity on our own \\
\hline & $\begin{array}{l}\text { Can there be interruption in our electricity } \\
\text { supply }\end{array}$ & -- \\
\hline & How does a battery work & How does a potato battery work \\
\hline & -- & How can we create battery from potatoes \\
\hline Skills & I can create electricity by myself at home & I can create electricity by myself at home \\
\hline \multirow[t]{5}{*}{$\begin{array}{l}\text { Affects (awareness, } \\
\text { interest, attitudes) }\end{array}$} & $\begin{array}{l}\text { Nature has cool things that are interesting to } \\
\text { know about }\end{array}$ & $\begin{array}{l}\text { Nature has cool things that are interesting to } \\
\text { know about }\end{array}$ \\
\hline & $\begin{array}{l}\text { We can learn from nature very useful things } \\
\text { for us }\end{array}$ & $\begin{array}{l}\text { We can learn from nature very useful things } \\
\text { for us }\end{array}$ \\
\hline & $\begin{array}{l}\text { I think it will be interesting for me to learn } \\
\text { about energy in nature }\end{array}$ & $\begin{array}{l}\text { It was interesting for me to learn about energy } \\
\text { in nature }\end{array}$ \\
\hline & $\begin{array}{l}\text { I think it will be interesting for me to learn to } \\
\text { create electricity from potatoes }\end{array}$ & $\begin{array}{l}\text { It was interesting for me to learn to create } \\
\text { electricity from potatoes }\end{array}$ \\
\hline & I am curious to see what we will learn & I enjoyed our learning session \\
\hline \multirow[t]{2}{*}{ Self-locus of control } & -- & I can teach others what we learned \\
\hline & -- & $\begin{array}{l}\text { Can we create enough energy for a number } \\
\text { of lamps? Do we need to get help from others } \\
\text { to do it? }\end{array}$ \\
\hline
\end{tabular}


the largest generated power was $0.78 \mathrm{~mW}$ (Figure $4 \mathrm{~d}$ ). The lowest battery galvanic apparent internal resistance was $1,424 \mathrm{Ohm}$ (Figure 4e). The maximum generated current density was $77 \mu \mathrm{A} \mathrm{cm} \mathrm{cm}^{-2}$ (Figure 4f) power density was $22 \mu \mathrm{W} \mathrm{cm}$ c $^{-2}$ (Figure $4 \mathrm{~g}$ ). The lowest galvanic internal resistivity was $42,320 \mathrm{Ohm} \cdot \mathrm{cm}$ (Figure $4 \mathrm{~h}$ ).

Pre-learning attitude, awareness, and interest

A short pre-learning questionnaire and a matching short postlearning questionnaire were used (Table 1. See Methods). In the pre-learning questionnaire, the children demonstrated a very high level of interest to learn about nature $(4.38 \pm 0.92$, on Likerttype $1-5$ scale), as may be expected for children participating in a nature and environment summer camp. They also expressed a very high level of agreement that nature holds practical and useful value for us. This insight and the interest to learn were correlated $(\mathrm{r}=0.406, \mathrm{p}=0.0)$.

The children were looking forward with much interest to learn and experience the creation of electricity from potatoes (4.23 \pm 1.23 , on Likert-type 1-5 scale); less interest was expressed to learn about energy in nature in general $(3.98 \pm 0.84)$. Although agreeing that we can create electricity by ourselves, they showed only an average level of confidence that they can do it. This infers a low confidence in their skills and locus of self-control. The interest to learn about creating electricity from potatoes was correlated to the interest to learn about energy in nature $(r=0.398$, $\mathrm{p}=0.0$ ), but no correlation was found to the concept of creating electricity at home or to the level of confidence that they can do it (Table S3). On the other hand, there was a positive correlation between the perception that it is possible to create electricity on our own and the confidence that they can actually do it although they had no experience yet $(\mathrm{r}=0.375, \mathrm{p}=0.0)$. Both findings show a positive interest and anticipation before the learning experience but little awareness and self-confidence in actually putting it to any practical use. We concluded that though they looked forward with positive anticipation to the learning session, they generally tended to expect it to be a curiosity with no practical implementation of actually producing electricity at home. Therefore, a major challenge for the learning activity for these children was to demonstrate and understand the practical implementation possibilities and to develop a perception of self-confidence in their capabilities to implement it. If the learning process would succeed with children in an affluent society in which power from the grid is constant and commonplace, it could potentially succeed even more in communities with no power from the grid. For future studies, we suggest to repeat this study with children in countries where power from the grid is scarce or non-existent and compare their attitude to the same process. It could be expected that they would be more aware from the start to the practical implementation yet this should be tested in a study.

\section{Post-learning impact}

Comparing the results before and after the learning session (Table 2 and Table 3), there was one significant difference - the perception that "I can create electricity at my home". Since appreciation and interest to learn about nature was rather high to start

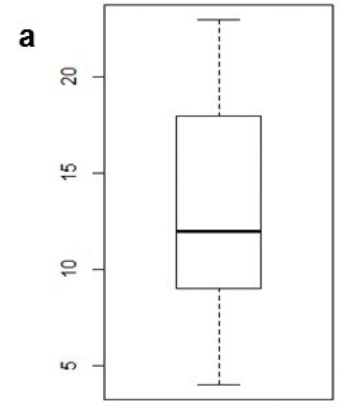

$\mathrm{N}$ cells in each battery

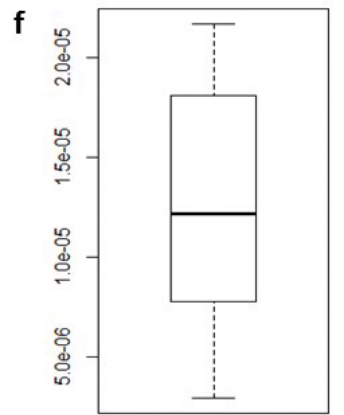

Current density $\left(\mathrm{A} / \mathrm{cm}^{2}\right)$

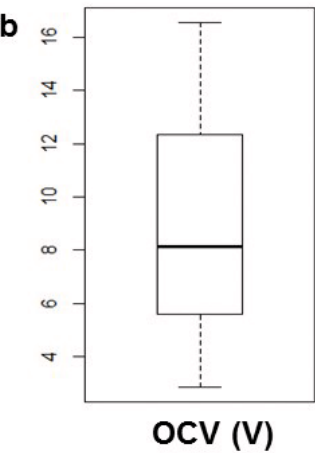

g

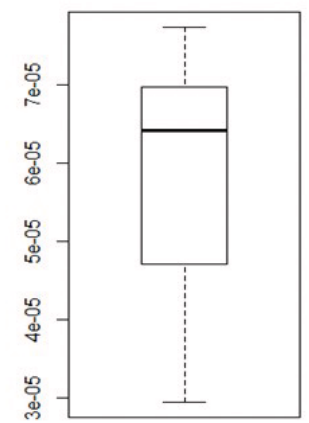

Power density $\left(\mathrm{W} / \mathrm{cm}^{2}\right)$
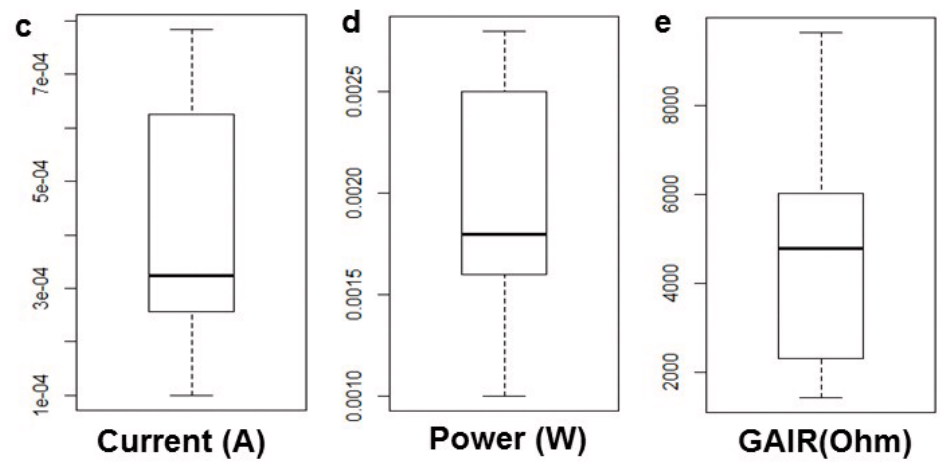

h

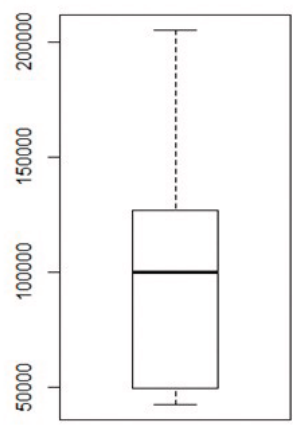

Internal Resistivity $(\mathrm{Ohm} \cdot \mathrm{cm})$

Figure 4. Distribution of assembled in competition batteries performance. (a) Number of cells in the final battery. (b) Open circuit voltage (OCV). (c) Current. (d) Power. (e) Galvanic apparent internal resistance (GAIR), which show how much energy is lost by battery internal resistance. (f) Current density. (g) Power density. (h) Internal resistivity. 
Table 2. Comparison of knowledge before and after the learning session. "Which ways do we get or create electricity" top 7 replies.

\begin{tabular}{|l|l|l|l|l|l|}
\hline Pre & \multicolumn{9}{l}{ Post } & & \\
\hline Reply & N & $\%$ & Reply & N & $\%$ \\
\hline From potatoes & 39 & 41 & From potatoes & 44 & 52 \\
\hline Electric Company/power stations & 20 & 21 & Sun, Solar energy & 15 & 18 \\
\hline Sun, Solar energy & 13 & 14 & Electric Company/power stations & 13 & 15 \\
\hline Don't know & 11 & 11 & declined to answer & 10 & 12 \\
\hline declined to answer & 9 & 9 & Don't know & 6 & 7 \\
\hline Static elec. (comb, balloon) & 7 & 7 & Coal & 3 & 4 \\
\hline Batteries & 6 & 6 & Water & 2 & 2 \\
\hline
\end{tabular}

Table 3. Comparison of knowledge before and after the learning session. "How can we create electricity on our own".

\begin{tabular}{|l|l|l|l|l|l|}
\hline Pre & \multicolumn{2}{|l|}{ Post } & N & $\%$ \\
\hline Reply & N & $\%$ & Reply & 51 & 60 \\
\hline Just stating "From potatoes & 39 & 41 & Just stating "From potatoes" & 10 & 12 \\
\hline Don't know & 13 & 14 & Declined to answer & 10 & 12 \\
\hline Declined to answer & 10 & 10 & From potatoes - explaining exactly how & 8 & 9 \\
\hline Sun, Solar energy & 6 & 6 & Don't know & 7 & 8 \\
\hline From potatoes - explaining exactly how & 5 & 5 & Sun, Solar energy & 2 & 2 \\
\hline Static elec. (comb, balloon) & 5 & 5 & Vinegar & 2 & 2 \\
\hline Batteries & 3 & 3 & Vegetables & & \\
\hline
\end{tabular}

with, a change in attitude was not expected to be significant. The challenge was in acquiring the skills and self-confidence or locus of control. A Student's t-test analysis shows that there was a significant change in the perception that children can create electricity at home by themselves with such simple ingredients such as potatoes $(\mathrm{t}(178)=-1.74, \mathrm{p}=0.008)$, with higher scores after the learning session.

There was a marked correlation between the children's perception that they can create electricity at their home and their thoughts that it was interesting for them to learn about energy in nature $(\mathrm{r}=0.328, \mathrm{p}=0.02)$, interesting to learn to create electricity from potatoes $(\mathrm{r}=0.390, \mathrm{p}=0.0)$ and that they enjoyed the learning session $(\mathrm{r}=0.430, \mathrm{p}=0.0)$, Table $\mathrm{S} 3$.

Children that thought they could create electricity at home, were more comfortable to feel they can teach others what they learned $(\mathrm{r}=0.375, \mathrm{p}=0.0)$. Again, so did children that thought it was interesting for them to learn about energy in nature $(r=0.443, p=0.0)$, interesting to learn to create electricity from potatoes $(r=0.617$, $\mathrm{p}=0.0)$ and that they enjoyed the learning session $(\mathrm{r}=0.636, \mathrm{p}=0.0)$. There was a high correlation between these insights (Table S3). These results show that achieving engagement and interest in the learning activity has a positive effect on developing perceptions of personal capabilities to actually create electricity at home from potatoes and to teach others.

These results for a learning session in the midst of an intensive summer camp show the potential of hands-on learning experience to set understanding and awareness and most of all, an appreciation of the personal capability to do it and make a change.

\section{Qualitative assessment of knowledge and attitude}

The purpose of the qualitative (open text) questions before the session was to find out the extent of awareness and the level of knowledge before the learning session took place (Table 2 and Table 3). The purpose of the questions after the session was to find out what they have learned and understood, what they remember and what was their attitude towards the information and insights from the learning session.

When asked before the learning session: "How do we get or create electricity?" only $24 \%$ of participants mentioned the electric company or power stations, $14 \%$ mentioned solar energy, $20 \%$ either declined to answer or said they did not know, 13\% talked about static electricity that they probably learned about in school or about batteries. Additional children mentioned non-relevant answers. Yet, the big surprise was that a remarkable $41 \%$ mentioned potato 
based battery as a source of electricity. It might be assumed that as they knew the questionnaire is related to the learning session, they thought that that was the reply we expected or wrote it for lack of any other thought.

In the post questionnaire, which was provided on the week following the activity, there was a marked difference in replies to the same questions. When asked this time how do we get or create electricity, $23 \%$ mentioned solar energy and other renewable energy sources. Potatoes reined high with 52\% of replies. Only $19 \%$ mentioned the electric company or power stations, and $15 \%$ declined to answer or said they did not know. These results show that a week after the learning session there was a high acclamation to the use of renewable energy sources for electricity and of the possible use of potato batteries as was experienced at the learning session.

Consequently, it appears that before the learning activity only $33 \%$ of the children mentioned valid sources of electricity at home for daily use. After the activity, there was a larger awareness to solar energy and other renewable sources. Non-relevant sources, such as lightning and static energy, that appeared on replies before the learning activity ( $13 \%$ of the children) were dropped after the activity.

When asked what they know about the possibility of creating electricity at home, $60 \%$ mentioned again potatoes, but an additional $12 \%$ knew to explain exactly how it is done. Another $5 \%$ talked about using lemon or vinegar and $8 \%$ talked about renewable energy sources. $24 \%$ either declined to answer or said they did not know, $8 \%$ talked about static electricity or batteries, and $3 \%$ said explicitly that it could not be done.

Before the learning session, $18 \%$ of participants knew about ways to create electricity at home, $23 \%$ had no idea, and $41 \%$ just wrote "potatoes". After the session, $15 \%$ of the children provided a detailed account of how to make a battery while an additional $18 \%$ provided a partial explanation. Additional $6 \%$ of participants tried to explain, but provided very wrong explanations. $21 \%$ declined to reply while $29 \%$ wrote they do "not know" or "don't remember". $13 \%$ knew to explain how the batteries work while $12 \%$ tried to but provided inaccurate explanations.
These levels of $33 \%$ being able to reproduce at least partially the battery-making process and $13 \%$ being able to repeat even more complex scientific or technological explanations show a very promising pilot study for the large scale adaptation of new energy systems through learning. These children were at a summer camp where they are playing and having fun most of the time and experience many workshops and learning activities as they go from one station to another. So they were surrounded with distractions and leisure activities. In these circumstances, it was notable to achieve such levels of attention and actual learning. A future study could evaluate the effect of repeated learning session or a more extended learning program to see if a larger percentage of renewable energy literacy, awareness and perception of personal capabilities is achieved.

Beyond these accounts of personal learning, the children were asked if they think now that $\mathrm{Zn} / \mathrm{Cu} /$ boiled potato batteries can provide cheap electricity in a simple, easy-to-make way. $54 \%$ agreed that yes, it can. $6 \%$ said it might be possible but in low volumes, not enough for real consumption. $5 \%$ said that it is impossible.

When asked so how can this be achieved, $62 \%$ did not reply to this question or said they did not know or did not remember. $31 \%$ said they could do it, mostly with the assistance of professional adults, such as a teacher or technician, or with the assistance of parents and family members. The break-down of these replies can be seen in Table 4.

Dataset 1. Questionnaire Raw Data Kids - Pre Learning

http://dx.doi.org/10.5256/f1000research.13228.d188989

Dataset 2. Questionnaire Raw Data Kids - Post Learning

http://dx.doi.org/10.5256/f1000research.13228.d188990

Dataset 3. Raw data for boiled potato batteries performance

http://dx.doi.org/10.5256/f1000research.13228.d188991

Table 4. Do the children think, after the learning session, that they can indeed produce enough energy for lamps at their home using the "make yourself a battery" toolkit and who they think they should do it with. $N$ is the number of children who replied.

\begin{tabular}{|l|l|l|}
\hline Reply & N & $\%$ \\
\hline Declined to answer & 34 & 40 \\
\hline Don't know, Don't remember & 18 & 20 \\
\hline Can be done with the help of a professional adult - technician, instructor & 10 & 12 \\
\hline Can be done but we need a lot of potatoes and metal electrodes & 10 & 12 \\
\hline Can be done with the help of parents and family members & 6 & 7 \\
\hline Impossible to do & 4 & 5 \\
\hline
\end{tabular}




\section{Conclusions}

Although renewable energy sources are continuously developed, their penetration and adaptation rate by rural population in developing countries is low. These low adaptation rates are associated with unawareness for an alternative to traditional methods solutions and low self-confidence to adopt the new methods. In this study, we developed a toolkit based on $\mathrm{Zn} /$ $\mathrm{Cu} /$ boiled potatoes batteries and non-formal teaching strategy that could enhance energy literacy and potentially displace the kerosene used for lighting in rural areas. Our pilot study on 96 children from an Israel summer camp, trained by youth leaders, showed that informal renewable energy education increases the awareness and self-confidence for battery assembly and electricity generation at home using simple available materials.

\section{Ethical statement}

The study was conducted according to the research guidelines of the Chief Scientist Office of the Ministry of Education. The educational institution, Teva HaSviva camp, approved of the research plan and informed all parents/guardians about the exact activities that the children would participate in, including interviewing the children, filming and distributing the information online for professional and educational purposes. We received written informed consent from the parents/guardians for the children to participate in the study as a part of their summer camp activities. The research involved only the use of non-sensitive, completely anonymous educational tests, using anonymous questionnaires and interview procedures that did not induce any undue psychological stress or anxiety. This study was done within normal education requirements in Teva HaSviva and to the best of our knowledge is exempt from ethical approval, as per Israel law, which follows Helsinki convention regulation.

\section{Data availability}

Dataset 1: Questionnaire Raw Data Kids - Pre Learning. DOI, 10.5256/f1000research.13228.d188989 $9^{40}$

Dataset 2: Questionnaire Raw Data Kids - Post Learning. DOI, 10.5256/f1000research.13228.d188990 ${ }^{41}$

Dataset 3: Raw data for boiled potato batteries performance. DOI, 10.5256/f1000research.13228.d188991 ${ }^{42}$

\section{Competing interests}

No competing interests were disclosed.

\section{Grant information}

The author(s) declared that no grants were involved in supporting this work.

\section{Acknowledgements}

The authors acknowledge the cooperation and assistance of the "Teva HaSviva" summer camp 2015 team and all the children who participated in this study.

\section{Supplementary material}

Supplementary File 1. Teaching materials for renewable energy learning session.

Click here to access the data.

Supplementary File 2. Pre and post learning questionnaires.

Click here to access the data.

Table S1. Zn/boiled potato battery characterization table as filled by children.

Click here to access the data.

Table S2. Electricity generation competition results. Measurements and calculations made by the children during competition. Va- voltage on external $100 \mathrm{ohm}$ resistor connected in series with the potato battery. OCV- open circuit voltage.

Click here to access the data.

Table S3. Pre and post learning questionnaires analysis.

Click here to access the data.

Figure S1. Digital images and illustrations of the potato lifecycle during the activity with 96 children. (a) Two bags of potatoes (about $4 \mathrm{~kg}$ each) were used during the activity. (b) The potatoes were cut into pieces. (c) The central part of each potato cut with $1-2 \mathrm{~cm}$ intervals, and divided between the central part and the edges. (d) The potatoes were boiled during about an hour. (e) The boiled potato were divided into a mash potato and for slices used the activity purposes $1 / 3$ and $2 / 3$ respectively. (f) All used potatoes after the activity with the children were composted.

Click here to access the data. 
1. Zyadin A, Puhakka A, Ahponen P, et al:: School students' knowledge, perceptions, and attitudes toward renewable energy in Jordan. Renew Energy. 2012; 45: 78-85.

Publisher Full Text

2. Boylan C: Exploring elementary students' understanding of energy and climate change. Int Electron J Elem Educ. 2008; 1(1).

Reference Source

3. Lambert JL, Lindgren J, Bleicher R: Assessing Elementary Science Methods Students' Understanding About Global Climate Change. Int J Sci Educ. 2012; 34(8): 1167-87.

Publisher Full Text

4. DOE: Energy Literacy: Essential Principals and Fndamental Concepts for Energy Eduction. 2014

Reference Source

5. Bodzin AM: What Do Eighth Grade Students Know About Energy Resources? In: NARST 2011 Annual International Conference. 2011. Reference Source

6. Aguirre-Bielschowsky I, Lawson R, Stephenson J, et al.: Energy literacy and agency of New Zealand children. Environ Educ Res. 2017; 23(6): 832-854. Publisher Full Text

7. Chen KL, Liu SY, Chen PH: Assessing multidimensional energy literacy of secondary students using contextualized assessment. Int J Environ Sci Educ. 2015; 10(2): 201-18 Reference Source

8. Fell MJ, Chiu LF: Children, parents and home energy use: Exploring motivations and limits to energy demand reduction. Energy Policy. 2014; 65 351-8.

Publisher Full Text

9. Chikaire JU, Ani AO, Nnadi FN, et al.: Energy extension and energy literacy for sustainable energy development in rural Nigeria. Agric Adv. 2015; 4(8): 84-92. Reference Source

10. Roth C: Environmental Literacy: Its Roots, Evolution and Directions in the 1990s. ERIC Clear Sci Math Environ Educ Columbus OH. 1992; 1-51. Reference Source

11. Simmons D: Environmental Education Materials: Guidelines for Excellence. NAAEE, 1996; 30 Reference Source

12. Kollmuss A, Agyeman J: Mind the Gap: why do people act environmentally and what are the barriers to pro-environmental behavior? Environ Educ Res. 2010; 8: $239-60$.

Publisher Full Text

13. Pe'er S, Goldman D, Yavetz B: Environmental Literacy in Teacher Training: Attitudes, Knowledge, and Environmental Behavior of Beginning Students. $J$ Environ Educ. 2007; 39(1): 45-59.

Publisher Full Text

14. Negev M, Sagy G, Garb Y, et al:: Evaluating the Environmental Literacy of Israeli Elementary and High School Students. J Environ Educ. 2008; 39(2): 3-20. Publisher Full Text

15. Carson R: The Sense of Wonder. 1950.

16. Reynolds HL Ed.: Teaching Environmental Literacy: Across Campus and Across the Curriculum. Indiana University Press; 2010. Reference Source

17. Orr DW: Ecological Literacy. In: Ecological Literacy - Education and the Transition to a Postmodern World. State University of New York Press; 1992; 85-95. Reference Source

18. Wilson AR: Fostering a sense of wonder during the early childhood days. Greyden books; 1993. Reference Source

19. Wilson RA: Starting Early: Environmental Education during the Early Childhood Years. ERIC Dig.1996.

Reference Source

20. Cobb E: The ecology of imagination in childhood. New York: Columbia University Press; 1977. Reference Source

21. Kirby SD, Guin AG, Chilcote AG: Creating the next generation of residential energy stewards using the energy transformation curriculum. Hous Soc. 2015; 42(3): 250-8.

Publisher Full Text

22. Fiskum TA, Jacobsen K: Relation Between the School Environment and the Children's Behaviour. Open Educ J. 2012; 5: 39-51. Publisher Full Tex
23. Eshach $\mathrm{H}$ : Bridging in-school and out-of-school learning: Formal, non-formal, and informal education. J Sci Educ Technol. 2007; 16(2): 171-90. Publisher Full Text

24. Henderson AT, Mapp KL: A New Wave of Evidence: The Impact of School, Family, and Community Connections on Student Achievement. Annual Synthesis 2002. National Center for Family and Community Connections with Schools. 2002. Reference Source

25. Volta A: On the Electricity Excited by the Mere Contact of Conducting Substances of Different Kinds. In a Letter from Mr. Alexander Volta, F. R. S. Professor of Natural Philosophy in the University of Pavia, to the Rt. Hon. Sir Joseph Banks, Bart. K. B. P. R. S. Philos Trans R Soc London. 1800; 90: 403-31, [cited 2016 Oct 13] Publisher Full Text

26. Kimemia D, Vermaak C, Pachauri S, et al:: Burns, scalds and poisonings from household energy use in South Africa: Are the energy poor at greater risk? Energy Sustain Dev. 2014; 18(1): 1-8. Publisher Full Text

27. Tedsen E: Black Carbon Emissions from Kerosene Lamps. Berlin; 2013. Reference Source

28. Mills $\mathrm{E}$ : Job creation and energy savings through a transition to modern offgrid lighting. Energy Sustain Dev. 2016; 33: 155-66.

Publisher Full Text

29. Mills E: Light for Life: Identifying and Reducing the Health and Safety Impacts of Fuel-based Lighting. UNEP. 2014. Reference Source

30. Were FH, Kamau GN, Shiundu PM, et al: Air and blood lead levels in lead acid battery recycling and manufacturing plants in Kenya. J Occup Environ Hyg. 2012: 9(5): 340-4.

PubMed Abstract | Publisher Full Text

31. Meyer PA, Brown MJ, Falk $\mathrm{H}$ : Global approach to reducing lead exposure and poisoning. Mutat Res. 2008; 659(1-2): 166-75. PubMed Abstract | Publisher Full Text

32. Suplido ML, Ong CN: Lead exposure among small-scale battery recyclers, automobile radiator mechanics, and their children in Manila, the Philippines. Environ Res. 2000; 82(3): 231-8 PubMed Abstract | Publisher Full Text

33. Gottesfeld P, Pokhrel AK: Review: Lead exposure in battery manufacturing and recycling in developing countries and among children in nearby communities. J Occup Environ Hyg. 2011; 8(9): 520-32. PubMed Abstract | Publisher Full Text

34. IFC: Energy Storage Trends and Opportunities in Emerging Markets [Internet]. 2017. Reference Source

35. Golberg A, Rabinowitch HD, Rubinsky B: Zn/Cu-vegetative batteries, bioelectrical characterizations, and primary cost analyses. J Renew Sustain Energy. 2010; 2(3): 033103 Publisher Full Text

36. Jayashantha N, Jayasuriya K, Wijesundera R: Biodegradable Plantain Pith fo Galvanic Cells. In: Proc 28th Tech Sess Inst Phys, Sri Lanka. 2012; 28: 92-7. Publisher Full Text

37. Muddassir M, Noor MA, Ahmed A, et al:: Awareness and adoption level of fish farmers regarding recommended fish farming practices in Hafizabad, Pakistan. J Saudi Soc Agric Sci. 2016. Publisher Full Text

38. Cuce E, Cuce PM: A comprehensive review on solar cookers. Appl Energy. 2013; 102: 1399-421. Publisher Full Text

39. Tiwari G, Saxena DRK: The Regenerative Energy Suspension System. Int J Sc Eng Res. 2015; 6(4): 1249. Reference Source

40. Polikovsky M, Sharon A, Golberg A: Dataset 1 in: Enhancing energy literacy in children using $\mathrm{zn} / \mathrm{cu} /$ potato batteries. F1000Research. 2017 Data Source

41. Polikovsky M, Sharon A, Golberg A: Dataset 2 in: Enhancing energy literacy in children using zn/cu/potato batteries. F1000Research. 2017. Data Source

42. Polikovsky M, Sharon A, Golberg A: Dataset 3 in: Enhancing energy literacy in children using zn/cu/potato batteries. F1000Research. 2017. Data Source 


\section{Open Peer Review}

\section{Current Peer Review Status:}

\section{Version 1}

Reviewer Report 11 February 2019

https://doi.org/10.5256/f1000research.14352.r43040

(C) 2019 Wake S. This is an open access peer review report distributed under the terms of the Creative Commons Attribution License, which permits unrestricted use, distribution, and reproduction in any medium, provided the original work is properly cited.

\section{Sue Wake}

Department of Architecture, Unitec Institute of Technology, Auckland, New Zealand

Your paper is interesting and relevant, but there are a number of areas that should be attended to, in order to strengthen its content readability and therefore its research value. I outline these here, in the order of reading:

1. You should state upfront that this is a pilot study and you are using child participants from affluent backgrounds, with the assumption that the results should be more valuable if applied to children from poorer backgrounds. You should provide some evidence of why you have this assumption - e.g. academic studies. Currently it is confusing as you introduce the idea of the pilot study further into the paper, and, even later, you admit that your subjects are from wealthy backgrounds and you recommend repeating the project with poorer children, since this could/should yield more positive results.

2. In your introduction you should more obviously credit the 2 models in Figs $1 \mathrm{a}$ and b. The way it is currently presented makes them seem like your own.

3. The paragraph in your intro starting 'Previous works...' is inelegantly written and not well linked to the topic of this paper. I recommend you reduce its length and more strongly connect it to your project in terms of your chosen focus (i.e. informal outside education).

4. It feels that there is a lost opportunity in this paper with regards making more of the youth leader role. This is an excellent example of 'peer learning' and reference to the literature on this (under children's participation) would give greater depth to your research and also extend the learning potential of your project. An example reference is Harry Shier's 'Pathways to participation' revisited: Learning from Nicaragua's child coffee workers ${ }^{1}$.

5. The second to last para of your intro, beginning 'At the same time ... the cost of light...' What do you mean by the cost of light? You then write 'This study was followed...' This sentence needs clarifying and more detail provided. For example, you might say 'A similar study from Sri Lanka found ... due to lack of awareness and poor self-confidence'. The word 'populations' should have 
the 's' removed.

6. In general you don't have enough references to the qualitative aspects of your research. More background on this will strengthen your argument considerably.

7. Your sections on 'Battery Performance Evaluation' and 'Electrical Production' sit very awkwardly in relation to the context of your research. I question what is the relevance of these sections? If it is important to your paper to produce these figures, then you need to put them into context and explain why they are relevant to your paper.

8. The information about the youth guides on P.5 is a little ambiguous as to whether the whole section just refers to them, or also to the other child participants. Perhaps give this a section heading e.g. 'Youth Guide Training'.

9. Also P.5 - I think you mean 'fertiliser', not 'fertilisation'.

10. 'Results \& Discussion' - the sentence about the longest battery should be changed to 'longest battery assembled by children' - to make sense.

11. There are a number of places where the English is not quite correct and the whole paper needs close editing for this. For example, where 'can' should be replaced by 'could'.

12. Is Fig 4 really of value to your paper? I am not convinced it is.

Overall, while your paper about the pilot study has some valuable outcomes, there are some significant issues with the number of assumptions you make, without evidence to support your rationale. Strong evidence of the benefits to children's education about alternative power sources and the viability of this method as a way of generating bio-energy (e.g. a whole lot of cooked potatoes presents a space and hygiene problem) seem to be rather absent from your paper. The observation that the $41 \%$ of participants that mentioned potatoes as an energy source, probably guessed this answer from inferences already made to them, sort of sums up the inconclusiveness of your results. This is reflected in your very brief conclusion. The paper needs to gain more substance through reducing some of the current content (as suggested) to allow space to focus more strongly and clearly on the background to children's learning by this method, linked through to your results. Currently there are too many loose ends. I also recommend that if you do any follow-up research, that you include the voice of the youth leaders and questions asked of the child and youth participants about how this way of learning compared to learning from adults.

\section{References}

1. Shier H: Pathways to participation' revisited: Learning from Nicaragua's child coffee workers. $A$ Handbook of Children's Participation: Perspectives from Theory and Practice. 2009. 215-227

\section{Is the work clearly and accurately presented and does it cite the current literature?} Partly

\section{Is the study design appropriate and is the work technically sound?}

Partly 
Are sufficient details of methods and analysis provided to allow replication by others? Yes

If applicable, is the statistical analysis and its interpretation appropriate? Partly

Are all the source data underlying the results available to ensure full reproducibility? Yes

Are the conclusions drawn adequately supported by the results? Partly

Competing Interests: No competing interests were disclosed.

Reviewer Expertise: Children and youth environments including participatory theory and children's inclusion in design decisions. Children's rights and environmental education.

I confirm that I have read this submission and believe that I have an appropriate level of expertise to confirm that it is of an acceptable scientific standard, however I have significant reservations, as outlined above.

Author Response 07 May 2019

Avigdor Sharon, Tel Aviv University, Tel Aviv, Israel

Thank you very much for your remarkable comments!

Here are replies, numbered according to comments.

1. Thank you for this insight. We will review this text and update accordingly.

2. The models in Figs $1 a$ and $b$ are indeed our own original charts. We will update the text to make it explicit

3. Thank you for this insight. We will review this text and update accordingly.

4. Indeed the youth leaders and peer learning were both major principles in the learning program. However, the sample of youth leaders was not large enough to be statistically significant. Therefore it was dropped. We will review and expand on this important topic. Thank you for the link.

5. Thank you for this insight. We will review this text and update accordingly.

6. Thank you for this insight. We will review this text and update accordingly.

7. Thank you for this insight. We will review this text and update accordingly.

8. This section refers to both the youth guides and to the children. But we will review if we can separate it to a youth guide training section and to a children education section.

9. The purpose was indeed to refer to 'use for fertilization'. Will expand it to explain the process of composting.

10. We will update accordingly the grammar of this sentence.

11. We will look for these places and update accordingly the grammar. 
12. Thank you again for this insight. We will review and update accordingly. We aimed indeed to include the voice of the youth leaders and find this feedback from them but the number of comments we received was not enough to justify inclusion. This would be a major issue to study in subsequent research

Competing Interests: No competing interests

Reviewer Report 28 January 2019

https://doi.org/10.5256/f1000research.14352.r42920

(c) 2019 Aguirre Bielschowsky I. This is an open access peer review report distributed under the terms of the Creative Commons Attribution License, which permits unrestricted use, distribution, and reproduction in any medium, provided the original work is properly cited.

\section{Ikerne Aguirre Bielschowsky}

School of Geography, University of Melbourne, Melbourne, VIC, Australia

I found this article interesting, useful for educators, well written and structured, and easy to follow. All of the raw data are made available, and the paper provides enough information to replicate the activity. The ideas presented here are innovative, and could have practical implications when applied in a low-income, off-the-grid context - indeed, I very much look forward to the follow-up study focusing on this topic. Before moving on, however, there are a few points that need to be clarified.

\section{Major comments}

1. Overall, I think that the framing of the study needs to be more explicit on what the authors wish to achieve and, crucially, what they hope to achieve here vs in a future study building on the current results. The abstract and introduction suggest a focus on developing the children's awareness of energy sources and their impact on society and the environment, as well as changing their energy behaviour. Yet the project itself mostly deals with the practical and scientific side of making electricity from potatoes. If the children were involved in discussions on (the impact of) current energy sources, and/or what difference using potatoes could actually make, please elaborate on what specific topics were discussed, how they were discussed, and the final understanding obtained by the children. I think the paper ought to be clear throughout on what are the secondary aims (apart from building selfconfidence) E.g. to (i) increase children's scientific knowledge on the process of electricity production; (ii) serve as a pilot study for a bigger research programme, which intends to improve living conditions in off-grid areas; and/or (iii) develop children's energy literacy. All three are worthwhile, and indeed all of them are mentioned here; however, not all of them are properly discussed, especially the energy literacy part. For example, the children are seemingly meant to realise the connection between generating electricity from potatoes and the wider socio-environmental implications of energy consumption and production. Understanding this complicated relationship likely would require different or additional 
learning experiences and follow-up evaluations.

2. According to the results (Table 2), most children think that electricity in general is generated from potatoes (both before and after the activity). This statement somewhat worries me, as it seems to reveal a misunderstanding about how electricity is actually produced in our society. Is there any indication that the children understand the broader context?

3. It would be helpful to have an idea of the characteristics of the participating children. How many boys vs girls participated? Are they mostly the children of academics, or do they come from underprivileged neighborhoods? What is their general socioeconomic background? Also, there ought to be some information on their previous experience. Is energy education compulsory in primary schools in Israel? Would the children have had previous experience doing experiments involving electricity, conductivity, etc.?

\section{Minor comments}

1. It is important to acknowledge in the introduction (e.g. bottom of p.2) that energy-related behaviours depend on external factors as well as internal/psychological ones, e.g. material culture and social norm. The latter are especially important when working with children.

2. Educators thinking of running this project with their students might benefit from an idea of how much a complete kit costs.

3. I think you mean technology "adoption", rather than "adaptation".

4. The section on "Qualitative assessment of knowledge and attitude" is somewhat repetitive, as it mostly recalls information already presented in the tables. I think it could be significantly shortened by discussing only the main trends. Also, I wonder whether the qualitative aspect of this section could be enhanced via some quotes, and a more in-depth discussion of the participants' opinions.

Is the work clearly and accurately presented and does it cite the current literature? Yes

Is the study design appropriate and is the work technically sound?

Yes

Are sufficient details of methods and analysis provided to allow replication by others? Yes

If applicable, is the statistical analysis and its interpretation appropriate? Yes

Are all the source data underlying the results available to ensure full reproducibility? Yes

Are the conclusions drawn adequately supported by the results? Yes

Competing Interests: No competing interests were disclosed.

Reviewer Expertise: Household energy consumption, energy literacy, environmental education, environmental consciousness and practices, and cultural comparisons. 
I confirm that I have read this submission and believe that I have an appropriate level of expertise to confirm that it is of an acceptable scientific standard.

Reviewer Report 14 May 2018

https://doi.org/10.5256/f1000research.14352.r29584

(C) 2018 Mutnuri S. This is an open access peer review report distributed under the terms of the Creative Commons Attribution License, which permits unrestricted use, distribution, and reproduction in any medium, provided the original work is properly cited.

\section{Srikanth Mutnuri}

Department of Biological Sciences, Birla Institute of Technology and Science, Pilani (BITS Pilani), Zuarinagar, India

The paper is well written. However I am not sure how the potato experiment can increase the awareness of children about clean energy possibilities, and increase their self-confidence in applying them. This experiment can certainly give knowledge about how electricity can be generated. I am not sure about it as clean energy possibilities. I feel this can be highlighted in the paper.

Is the work clearly and accurately presented and does it cite the current literature? Yes

Is the study design appropriate and is the work technically sound?

Yes

Are sufficient details of methods and analysis provided to allow replication by others? Yes

If applicable, is the statistical analysis and its interpretation appropriate? Yes

Are all the source data underlying the results available to ensure full reproducibility? Yes

Are the conclusions drawn adequately supported by the results? Yes

Competing Interests: No competing interests were disclosed.

I confirm that I have read this submission and believe that I have an appropriate level of expertise to confirm that it is of an acceptable scientific standard. 
The benefits of publishing with F1000Research:

- Your article is published within days, with no editorial bias

- You can publish traditional articles, null/negative results, case reports, data notes and more

- The peer review process is transparent and collaborative

- Your article is indexed in PubMed after passing peer review

- Dedicated customer support at every stage

For pre-submission enquiries, contact research@f1000.com 